Marquette University

e-Publications@Marquette

Finance Faculty Research and Publications

Finance, Department of

$1-1-2001$

\title{
The Evolution of Real Estate in the Economy
}

Dapeng $\mathrm{Hu}$

Citicorp Mortgage, Inc.

Anthony Pennington-Cross

Marquette University, anthony.pennington-cross@marquette.edu

Published Version. Journal of Real Estate Portfolio Management, Volume 7, No. 2, pp 169-176 (2001). Permalink. (C) 2001 American Real Estate Society. Used with permission.

Anthony Pennington-Cross was affiliated with the Research Institute of Housing America at the time of publication. 


\section{The Evolution of Real Estate in the Economy}

Executive Summary. While the economy as a whole has been rapidly changing in response to technological in. novation, real estate has evolved from a depository of wealth for households and assets for corporations into a. major force in the debt and equity markets. In contrast, the role of real estate as a contributor to the nation's output and income has remained steady at approximately $11 \%$ of gross domestic product.
* Citicorp Mortgage, Inc. St Louis, MO 6.3141 or Dapeng. Huciciticorp.com.

* Research Institute of Housing America, Washington, DC 20006 or anthony_pennington-cross-ambar.org. by Dapeng $\mathrm{Hu}^{*}$

Anthony Pennington-Cross ${ }^{* *}$

\section{Introduction}

The fast growth of the high tech and Internetrelated industries has changed the landscape of the economy in the United States. In 1999, the economy completed its tenth consecutive year of expansion, marking the longest expansion in history. As a result, the concept of a "New Economy" has become widely accepted. What is the role of real estate in the New Economy? How will the real estate industry change in the future? One approach to answer these questions is to look back in time and examine the patterns of growth and decline of real estate in various parts of the economy.

This article examines economic indicators to depict the evolution of the real estate industry's role in the economy over time. This examination spans the early 1980s through 1999, a period chosen for two reasons. First, important financial innovations in the real estate industry, such as real estate investment trusts (REITs) and mortgage-backed securities (MBS) occurred during this period. Secondly, this was also the period during which we saw the rapid growth of high-tech industries and the formation of dot-com companics.

A few studies have tried to estimate the size of the entire real estate industry or the aggregate value of all real estate assets. Miles, Machi and Hopkins (1994) and Viles and Tolleson (1997) provided estimates of the aggregate value of investable real estate assets in public and private markets. In its America's Real Estate series, the Urban Iand Institute (ULI) also has attempted to calculate and publish such a statistic, which incorporates comprehensive data tables of real estate component 
values. The method used in these articles is a detailed accounting approach. The entire real estate market was divided into two markets, public and private; each of these was further divided into several segments. Data on transactions and flow of funds provided a reasonably accurate estimation of the total value of real estate in public markets. However, documenting the aggregate value of nonsecuritized or private market assets is not as straightforward.

This detailed accounting method approach has two disadvantages. First, it requires a huge amount of data, which generally are not available either in cross section or over time. For example, commercial real estate is one of the largest components of the private market. However, there is no direct data information on the market value of real estate held by corporations. In addition, previous studies rely heavily on arbitrarily determined parameters to estimate asset values. These parameters are almost always time invariant. Given that results are sensitive to these key parameters, the lack of time variation limits the usefulness of the results when examining changes across decades. It is not surprising that there is a wide range of estimates reflecting the lack of agreement on the true size of the real estate pie.

Rather than creating one arbitrarily determined aggregate number, our approach is to create several indicators based on more reliable data that reflect several aspects of the real estate industry. The aspects include real estate in gross domestic product (GDP), which reflects the annual flow of value added by the real estate industry; real estate's share in the total wealth of households and businesses; real estate in the debt market, and real estate in the stock market.

Our key conclusions include the following. In terms of the value added in GDP, the role of the real estate industry is quite steady over time. About $11 \%$ of output each year is attributable to the real estate industry. In terms of household and corporation asset allocations, the importance of real estate has been declining. One of the contributors to this phenomenon is the very strong performance of the stock market. In the capital markets, the prominence of REITs in the stock market has increased since 1985 . However, it remains a very small fraction of the overall equity market. Finally, the role of real estate in the debt market has steadily increased, and the securitization of residential and commercial mortgages has increased real estate's scope in debt markets.

\section{Real Estate in the Economy: Several Indicators}

\section{A Flow Measure Value Added in GDP}

Exhibit 1 shows the allocation of GDP to the real estate industry as a whole and for various components of the industry. Following the ULI's approach (ULI, 1998), GDP is allocated to the real estate industry based on the gross output originating from the construction, real estate service, real estate finance and insurance sectors. To estimate how much of the output from the finance and insurance sector can be attributed to real estate, we calculate the fraction of outstanding credit that is attributed to mortgages from in the Federal Reserve Bulletin's Table 1.59 Summary of Credit Market Debt Outstanding. This estimate should be viewed as a lower bound. To estimate the output of real estate services, the output from owneroccupied homes is subtracted from the total output of the real estate sector.

While the percentage of value added attributed to real estate is fairly steady over time, its importance actually grew slightly in the late 1990s. Real estate's share of GDP increased from $10.7 \%$ in 1993 to $11.3 \%$ in 1997 . While this may seem fairly trivial, if share is held constant at the 1993 level, real estate's output would be $\$ 868$ billion lower. In other words, real estate has grown $5 \%$ faster than would have been expected if the market structure were unchanged since 1993. The substantial innovations in real estate finance and insurance must contribute to this growth.

In sum, real estate is as important a part of the economy as ever, in terms of economic flow. Some parts of the industry, especially those related to finance and capital market, have increased share in GDP, while others (i.e., services) have remained 


\section{Exhibit 1}

Allocation of GDP to the Real Estate Industry

\begin{tabular}{|c|c|c|c|c|c|c|c|c|c|}
\hline \multirow[b]{2}{*}{ Year } & \multirow{2}{*}{$\frac{\text { Total GDP }}{\text { Dollars }}$} & \multicolumn{2}{|c|}{ Real Estate Industry } & \multicolumn{2}{|c|}{ Construction } & \multicolumn{2}{|c|}{ Real Estate Services } & \multicolumn{2}{|c|}{$\begin{array}{l}\text { Real Estate Finance } \\
\text { and Insurance }\end{array}$} \\
\hline & & Dollars & Percentage & Dollars & Percentage & Dollars & Percentage & Dollars & Percentage \\
\hline 1988 & $5,049.6$ & 598.4 & 11.9 & 233.4 & 4.6 & 268.5 & 5.3 & 96.5 & 1.9 \\
\hline 1989 & 5.438 .7 & 638.8 & 11.7 & 242.2 & 4.4 & 292.7 & 5.3 & 103.9 & 1.9 \\
\hline 1990 & $5,743.8$ & 661.4 & 11.5 & 245.2 & 4.2 & 306.7 & 5.3 & 109.5 & 1.9 \\
\hline 1991 & $5,916.7$ & 663.2 & 11.2 & 228.8 & 3.8 & 312.8 & 5.3 & 121.5 & 2.0 \\
\hline 1992 & $6,244.4$ & 672.0 & 10.8 & 229.7 & 3.6 & 330.0 & 5.3 & 112.3 & 1.8 \\
\hline 1993 & 6.558 .1 & 699.8 & 10.7 & 242.4 & 3.7 & 338.5 & 5.2 & 118.9 & 1.8 \\
\hline 1994 & $6,947.0$ & 747.4 & 10.8 & 268.7 & 3.8 & 359.0 & 5.2 & 119.7 & 1.7 \\
\hline 1995 & $7,269.6$ & 796.1 & 11.0 & 286.4 & 3.9 & 376.1 & 5.2 & 133.6 & 1.8 \\
\hline 1996 & 7.661 .6 & 859.6 & 11.2 & 311.9 & 4.0 & 400.9 & 5.2 & 146.8 & 1.9 \\
\hline 1997 & $8,110,9$ & 912.5 & 11.3 & 328.8 & 4.0 & 416.6 & 5.1 & 167.1 & 2.0 \\
\hline
\end{tabular}

Notes: Data sources are National Accounts Data, BEA and the Federal Reserve Bulletin. All dollars are current dollars in billions. GDP is allocated to the real estate industry based on the gross output originating from the construction, real estate services, and real estate finance and insurance sectors (real estate industry = construction + real estate services + real estate finance and insurance). To estimate the output of real estate services the output from owner occupied homes is subtracted from total output of the real estate sector. The output of owner occupied homes is estimated from Table 8.19 of the National Income and Product Accounts gross housing product of owner occupied farm and nonfarm housing (lines 89 and 97). To estimate how much of the output from the finance and insurance sector can be attributed to real estate we calculate the fraction of outstanding credit that is attributed to mortgages from Table 1.59 Summary of Credit Market Debt Outstanding as reported in the Federal Reserve Bulletin. All F\&l is defined as the sum of reported gross output from depository institutions. nondepository institutions, security and commodity brokers, insurance carriers, and holding and other investment offices.

constant and still others have decreased. However, a different conclusion is reached when we examine the asset base.

\section{Stock Measures Household and Corporate Asset Allocation}

Exhibits 2 and 3 document how much of household and nonfinancial corporate assets are allocated to real estate. In both exhibits, total assets refer to all tangible and financial assets held; real estate assets refer to tangible real estate assets only.

From Exhibit 2, we can see that the share of real estate assets held by U.S. households was quite steady throughout most of the $1980 \mathrm{~s}$, but began declining at the end of the decade. This trend continued through 1999, the last year for which we have data. In the $1980 \mathrm{~s}$, real estate assets consistently accounted for about $31 \%$ of household and nonprofit assets, but by the end of 1999 that fraction was just less than $23 \%$. Meanwhile, the importance of stocks and mutual funds increased rapidly from $7.5 \%$ in the 1985 to $22.7 \%$ in 1999 . In 1999, stocks and mutual funds became a larger part of household assets than real estate for the first time. In addition, pension fund reserves also increased rapidly during this period.

Over the long run, it is not surprising to see the decline in real estate as a depository of household wealth. For households, owner-occupied homes represent the vast majority of real estate wealth. Because the income elasticity of housing demand has been estimated in the range of 0.7 to 1.0 (Mills, 1999), spending on housing will increase less than the growth in income. Thus, when household income or wealth increases by $10 \%$, housing expenditure increases by less than $10 \%$.

In addition, the improved condition of financial markets may provide an additional impetus for the declining role of real estate as a mechanism for holding wealth. Exhibit 2 shows that stocks and mutual fund holdings have increased from about $7 \%$ in 1982 to more than $22 \%$ of total wealth in 1999. Stock prices have increased at a much faster rate than home prices, especially in the 1990 s. This can be seen in Exhibit 4, which plots the appreciation rate on the Freddie Mac Repeat Sales House Price Index versus the S\&P 500 Index. Even if households were to expend the same proportion 


\section{Exhibit 2}

Real Estate Assets in the Total Wealth of Households and Nonprofit Organizations: 1982-1999

\begin{tabular}{|c|c|c|c|c|c|c|c|}
\hline \multirow[b]{2}{*}{ Year } & \multicolumn{2}{|c|}{ Dollar Allocation (\$billions) } & \multicolumn{5}{|c|}{ Percentage Allocation (\%) } \\
\hline & Total Assets & $\begin{array}{l}\text { Real Estate } \\
\text { Assets }\end{array}$ & Real Estate & $\begin{array}{l}\text { Other Tangible } \\
\text { Assets }\end{array}$ & $\begin{array}{l}\text { Corporate Equities and } \\
\text { Mutual Fund Shares }\end{array}$ & $\begin{array}{l}\text { Pension Fund } \\
\text { Reserves }\end{array}$ & $\begin{array}{l}\text { Other Financial } \\
\text { Assets }\end{array}$ \\
\hline 1982 & 12,673 & 3,999 & 31.5 & 8.3 & 7.1 & 10.1 & 42.9 \\
\hline 1983 & 13.710 & 4,181 & 30.5 & 8.1 & 7.5 & 11.1 & 42.6 \\
\hline 1984 & 14,803 & 4.630 & 31.2 & 8.1 & 6.6 & 11.4 & 42.5 \\
\hline 1985 & 16.684 & 5,235 & 31.3 & 7.8 & 7.5 & 12.5 & 40.8 \\
\hline 1986 & 18,392 & 5,719 & 31.1 & 7.7 & 9.0 & 12.6 & 39.4 \\
\hline 1987 & 19,651 & 6,177 & 31.4 & 7.9 & 8.5 & 12.7 & 39.4 \\
\hline 1988 & 21.461 & 6,712 & 31.2 & 7.8 & 9.2 & 12.7 & 38.9 \\
\hline 1989 & 23,583 & 7,296 & 30.9 & 7.7 & 10.3 & 13.6 & 37.4 \\
\hline 1990 & 24,307 & 7,405 & 30.4 & 7.9 & 9.3 & 14.2 & 38.0 \\
\hline 1991 & 25,920 & 7,477 & 28.8 & 7.6 & 12.1 & 14.9 & 36.3 \\
\hline 1992 & 27,000 & 7,664 & 28.3 & 7.6 & 13.3 & 15.6 & 35.0 \\
\hline 1993 & 28,429 & 7,804 & 27.4 & 7.6 & 14.8 & 16.4 & 33.6 \\
\hline 1994 & 29,477 & 8,017 & 27.2 & 7.7 & 13.9 & 16.8 & 34.2 \\
\hline 1995 & 32,610 & 8,398 & 25.7 & 7.3 & 16.5 & 17.7 & 32.7 \\
\hline 1996 & 35,483 & 8,833 & 24.8 & 6.9 & 17.5 & 18.7 & 31.9 \\
\hline 1997 & 39,697 & 9,517 & 23.9 & 6.4 & 19.5 & 19.9 & 30.2 \\
\hline 1998 & 43,508 & 10,238 & 23.5 & 6.1 & 20.3 & 20.9 & 29.1 \\
\hline 1999 & 48,889 & 11,088 & 22.7 & 5.8 & 22.7 & 21.2 & 27.6 \\
\hline
\end{tabular}

Note: All dollars are current dollars in billions. Total asset includes all the tangible asset and financial asset. Real estate asset refers tangible real estate asset only. Asset values are at market. Data sources: Flow of Funds, Z1, and Tables \& Survey of Consumer Finance.

\section{Exhibit 3}

\section{Real Estate Assets in the Total Wealth of Non-Financial Companies: 1982-1999}

\begin{tabular}{|c|c|c|c|c|c|}
\hline \multirow[b]{2}{*}{ Year } & \multicolumn{2}{|c|}{ Dollar Allocation (\$billions) } & \multicolumn{3}{|c|}{ Percentage Allocation (\%) } \\
\hline & Total Assets & Real Estate Assets & Real Estate & Other Tangible Assets & Financial Assets \\
\hline 1982 & 6,145 & 2,514 & 40.9 & 31.9 & 27.2 \\
\hline 1983 & 6,463 & 2,588 & 40.0 & 31.5 & 28.5 \\
\hline 1984 & 7,013 & 2,732 & 39.0 & 30.9 & 30.1 \\
\hline 1985 & 7.502 & 2,854 & 38.0 & 30.2 & 31.7 \\
\hline 1986 & 7,838 & 2.936 & 37.5 & 30.1 & 32.4 \\
\hline 1987 & 8,343 & 3,083 & 37.0 & 29.9 & 33.2 \\
\hline 1988 & 9,074 & 3,288 & 36.2 & 29.2 & 34.6 \\
\hline 1989 & 9.620 & 3,471 & 36.1 & 29.1 & 34.8 \\
\hline 1990 & 9,828 & 3,440 & 35.0 & 30.0 & 35.0 \\
\hline 1991 & 9,736 & 3.254 & 33.4 & 30.2 & 36.4 \\
\hline 1992 & 9,723 & 3.012 & 31.0 & 31.1 & 37.9 \\
\hline 1993 & 10,070 & 2.901 & 28.8 & 31.3 & 39.9 \\
\hline 1994 & 10,691 & 3.074 & 28.8 & 31.4 & 39.8 \\
\hline 1995 & 11,494 & 3,203 & 27.9 & 31.1 & 41.1 \\
\hline 1996 & 12,266 & 3,354 & 27.3 & 30.4 & 42.3 \\
\hline 1997 & 13,339 & 3,756 & 28.2 & 29.3 & 42.5 \\
\hline 1998 & 14,251 & 4,203 & 29.5 & 28.4 & 42.1 \\
\hline 1999 & 15,380 & 4,411 & 28.7 & 28.2 & 43.1 \\
\hline
\end{tabular}

Notes: Data sources are Flow of Funds, $\mathrm{Z1}$, and tables from various years. All dollars are current dollars in billions. Total asset includes all the tangible assets and financial assets. Real estate asset refers to tangible real estate only. Asset values are at market value. 


\section{Exhibit 4 \\ House Price Index vs. S\&P Index}

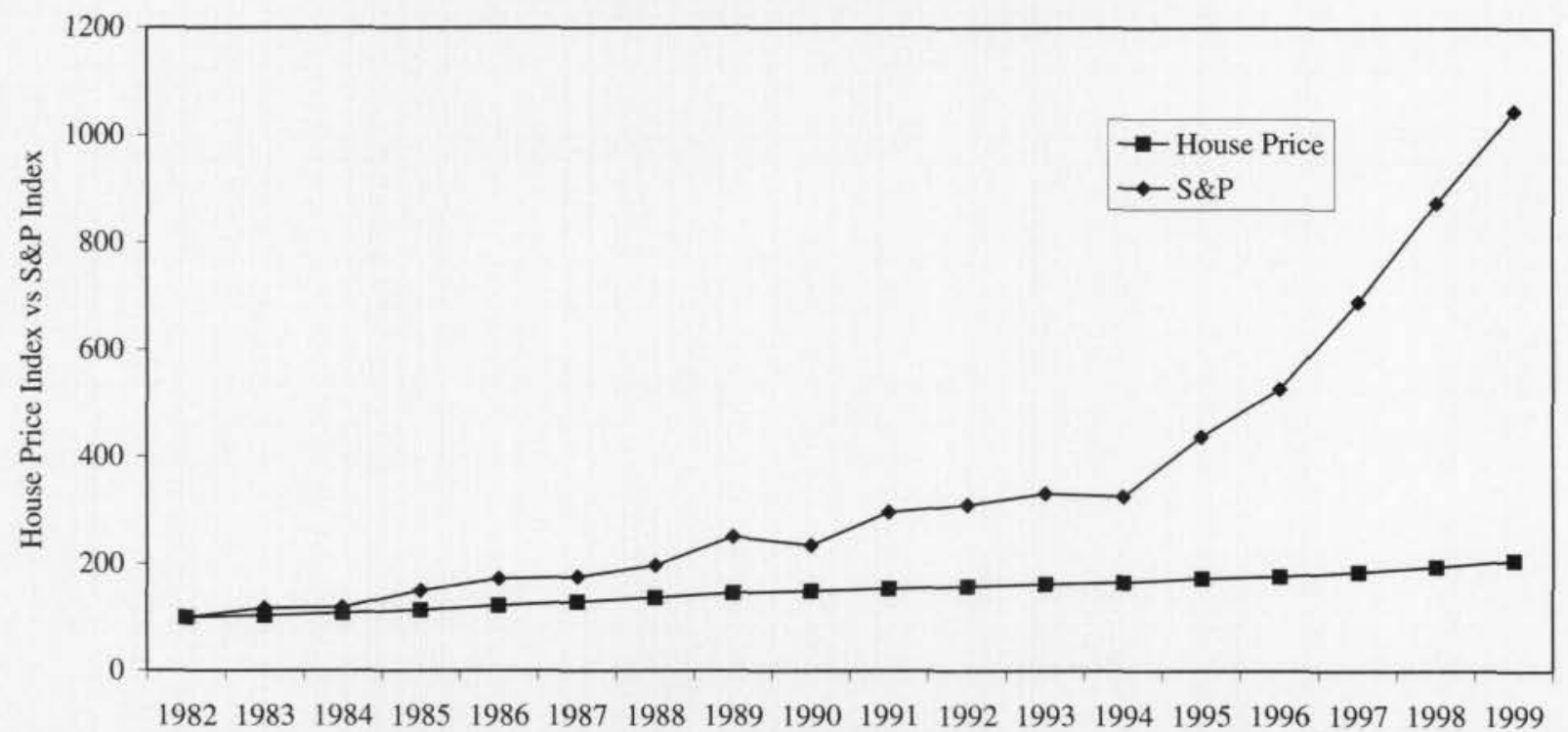

Note: Housing price index is from Freddie Mac Repeat Sale Housing Price Index. Base year is 1982 when both indexes are normalized into 100.

of their income on real estate assets each year, the lower return on housing would drive down the fraction of wealth held in such assets. In addition, the lower cost of investing in the stock market, along with the momentum of investing associated with its rise in the $1990 \mathrm{~s}$, make it likely that households have been shifting some money from real estate into stocks to diversify their portfolios. As long as the economy is strong and the stock market performs well, one would expect further declines in the fraction of household assets allocated to real estate (primarily owner-occupied homes). That said, the volatility in the stock market is much higher than in the housing market, and that volatility has been increasing recently. If a major market correction occurs, it is possible that the fraction of household wealth held in real estate will increase.

Finally, the baby-boomer generation may provide another reason for real estate's recent decline in share of household wealth. As baby boomers approach retirement age, they should be focusing on saving more money for retirement. The increase in the pension fund reserves is evidence of this behavior. However, once this group actually enters retirement, individuals will begin to use their savings and wealth for consumption. This will ultimately reduce the demand for stocks and bonds.

Exhibit 3 shows the changes in asset allocation for nonfinancial companies. As with households, there is a declining share for real estate in corporate wealth. In the early $1980 \mathrm{~s}$, the fraction of real estate assets held by these companies was as high as about $41 \%$, but by the end of 1990 s it dropped to about $28 \%$. This decline was most dramatic in the early 1990 s.

The decline reflects the potential influences of at least two factors. First, the decrease in the relative value of real estate naturally reduces the fraction of assets held in real estate. That is, the values of non-real estate assets simply have appreciated more. Second, there has been a decline in the incentives for nonfinancial companies to hold real estate. A number of researchers including Linneman (1998) and Gyourko and Deng (1999) have argued that the ownership of too much real estate can and does hurt firms, resulting in lower returns in the long run. Hence, the decline in the share of scarce corporate capital being devoted to real estate may reflect increasingly sound management practice. ${ }^{1}$ 
Exhibit 5

Real Estate Debt: Debt Outstanding 1985-1998

\begin{tabular}{|c|c|c|c|c|c|c|c|c|c|c|c|c|c|}
\hline Year & $\begin{array}{l}\text { Total Debt } \\
\text { Outstanding } \\
\text { (\$) } \\
\text { (A) }\end{array}$ & $\begin{array}{l}\text { Mortgage } \\
\text { Owed by } \\
\text { Nonfinancial } \\
\text { Sector (\$) } \\
\text { (B) }\end{array}$ & $\begin{array}{l}\text { GSES }(\$) \\
(C)\end{array}$ & $\begin{array}{l}\text { Federal } \\
\text { Related } \\
\text { Mortgage } \\
\text { Pools (\$) } \\
\text { (D) }\end{array}$ & $\begin{array}{l}\text { Mortgage } \\
\text { Companies } \\
\text { (\$) } \\
\text { (E) }\end{array}$ & $\begin{array}{l}\text { REITS } \\
(\$) \\
\text { (F) }\end{array}$ & $\begin{array}{l}\text { Agency } \\
\text { CMOS } \\
(\$)^{a} \\
(G)\end{array}$ & $\begin{array}{l}\text { Privately } \\
\text { Issued Home } \\
\text { MBS }(\$)^{b} \\
\text { (H) }\end{array}$ & $\begin{array}{l}\text { Non- } \\
\text { Agency } \\
\text { CMBS } \\
\text { (\$) } \\
\text { (I) }\end{array}$ & $\begin{array}{l}\text { Debt by } \\
\text { Finance } \\
\text { Companies } \\
\text { for Mortgage } \\
(\$)^{c} \\
(J)\end{array}$ & $\begin{array}{l}\text { Total Real } \\
\text { Estate } \\
\text { Debt (\$) } \\
\text { (K) }\end{array}$ & $\begin{array}{l}\text { Real } \\
\text { Estate } \\
\text { Debt } \\
\text { Fraction } \\
(\%) \\
\text { (L) }\end{array}$ & $\begin{array}{l}\text { MBS Total } \\
\text { Debt } \\
\text { Fraction } \\
\text { (\%) } \\
\text { (M) }\end{array}$ \\
\hline 1985 & 8,627 & 2,376 & 263 & 369 & 16 & 8 & 10 & 24 & 1 & 19 & 3,085 & 35.8 & 7.7 \\
\hline 1986 & 9,804 & 2,661 & 278 & 531 & 25 & 13 & 53 & 17 & 2 & 24 & 3,604 & 36.8 & 9.0 \\
\hline 1987 & 10.816 & 2,963 & 308 & 670 & 14 & 21 & 81 & 28 & 4 & 28 & 4,118 & 38.1 & 10.1 \\
\hline 1988 & 11,855 & 3,279 & 353 & 745 & 14 & 25 & 106 & 35 & 7 & 31 & 4,594 & 38.8 & 10.5 \\
\hline 1989 & 12,822 & 3,549 & 378 & 869 & 24 & 27 & 98 & 43 & 10 & 36 & 5,035 & 39.3 & 10.9 \\
\hline 1990 & 13,745 & 3,804 & 398 & 1,019 & 24 & 28 & 103 & 55 & 12 & 44 & 5,488 & 39.9 & 11.5 \\
\hline 1991 & 14,393 & 3,954 & 407 & 1,156 & 22 & 29 & 89 & 100 & 18 & 44 & 5,818 & 40.4 & 12.3 \\
\hline 1992 & 15,194 & 4,068 & 448 & 1.272 & 30 & 28 & 71 & 151 & 29 & 46 & 6,143 & 40.4 & 13.0 \\
\hline 1993 & 16,165 & 4,203 & 529 & 1,357 & 30 & 30 & 90 & 184 & 40 & 44 & 6,505 & 40.2 & 13.6 \\
\hline 1994 & 17,209 & 4.372 & 701 & 1,472 & 19 & 40 & 110 & 206 & 47 & 47 & 7.013 & 40.8 & 14.7 \\
\hline 1995 & 18,439 & 4.569 & 807 & 1,570 & 17 & 45 & 133 & 224 & 54 & 51 & 7.469 & 40.5 & 15.1 \\
\hline 1996 & 19,766 & 4,849 & 897 & 1,711 & 21 & 57 & 137 & 259 & 71 & 59 & 8,061 & 40.8 & 15.6 \\
\hline 1997 & 21,157 & 5,138 & 995 & 1,826 & 16 & 96 & 141 & 312 & 97 & 63 & 8,684 & 41.1 & 15.9 \\
\hline 1998 & 23,364 & 5,612 & 1,274 & 2.018 & 18 & 159 & 179 & 403 & 157 & 73 & 9,893 & 42.3 & 17.3 \\
\hline 1999 & 25,614 & 6,238 & 1,592 & 2,292 & 18 & 167 & 224 & 455 & 198 & 87 & 11,271 & 44.0 & 18.6 \\
\hline
\end{tabular}

mated by the Authors. The number equals mortgage asset times debt to total asset ratio in finance companies. 
Exhibit 6

Real Estate in the Equity Market: 1985-1999

\begin{tabular}{lccc}
\hline & $\begin{array}{l}\text { Total Equity } \\
\text { Date }\end{array}$ & $\begin{array}{l}\text { Market } \\
\text { Capitalization } \\
\text { of all REITs }\end{array}$ & $\begin{array}{l}\text { Number of } \\
\text { Public REITs }\end{array}$ \\
\hline 31-Dec-85 & $2,195,914$ & 7.67 & 82 \\
31-Dec-86 & $2,467,299$ & 9.92 & 96 \\
31-Dec-87 & $2,467,792$ & 9.70 & 110 \\
30-Dec-88 & $2,702,045$ & 11.44 & 117 \\
29-Dec-89 & $3,290,805$ & 11.66 & 120 \\
31-Dec-90 & $2,970,824$ & 8.74 & 119 \\
31-Dec-91 & $3,982,063$ & 12.97 & 138 \\
31-Dec-92 & $4,375,079$ & 15.91 & 142 \\
31-Dec-93 & $5,020,231$ & 32.16 & 189 \\
30-Dec-94 & $4,964,998$ & 44.31 & 226 \\
29-Dec-95 & $6,732,165$ & 57.54 & 219 \\
31-Dec-96 & $8,237,516$ & 88.78 & 199 \\
31-Dec-97 & $10,699,532$ & 140.53 & 211 \\
31-Dec-98 & $13,175,871$ & 138.30 & 210 \\
31-Dec-99 & $17.642,728$ & 124.26 & 210 \\
\hline
\end{tabular}

Notes: Dollars in billions. Data sources: CRSP Indices, NASDAO and NAREIT. The total market value includes total market value at the NYSE, AMSE and NASDAO.

\section{Real Estate Equity and Debt}

This section focuses on the growth of real estaterelated equity and debt capital markets. Exhibits 5 and 6 are constructed to examine the evolution of real estate in the capital markets. Exhibit 5 provides annual data on outstanding debt and Exhibit 6 depicts the role of REITs in the stock market.

Exhibit 5 shows a steady increase in the fraction of total outstanding debt that is real estaterelated. Real estate debt is defined as all debt owed by real estate companies or non-real estate companies, but for real estate purposes. Using the Federal Reserve Flow of Funds data, this includes mortgage debt (home and commercial), government-sponsored enterprise (GSE) securities and collateral mortgage obligations (CMOs), federal government-related mortgage pools, debt owed by mortgage companies and REITs, privately issued home MBS, nonagency commercial mortgagebacked securities (CMBS) and debt owed by banks for mortgage financing. The only parts missing from this calculation are municipal bonds and nonreal estate company corporate bonds that are used to finance real estate projects.

Total real estate debt outstanding in 1985 was about $\$ 3$ trillion, while it was about $\$ 11.3$ trillion in 1999. The real estate fraction of total debt outstanding was $35.8 \%$ in 1985 , while it climbed to $44 \%$ in 1999 . Excluding mortgage debt owed by households and nonfinancial companies, nonmortgage real estate debt (primarily in bonds, with some commercial loans and commercial papers) increased even more rapidly. In addition, nonmortgage real estate debt was only about $8 \%$ of total outstanding debt in 1985 ; it was about $19 \%$ in 1999. In summary, these results show that in the debt market, real estate is becoming increasingly important and may in the foreseeable future constitute the majority of the debt market.

One of the most important causes of the growth of real estate debt is securitization. In the 1980 s and early 1990s, home MBS experienced the fastest growth. The issuance of CMBS surged in the 1990 s, although there was a break in late 1998 and early 1999. The continued growth in these parts of the market will hinge largely on the ability of CMBS to provide increased liquidity and stability.

Exhibit 6 turns to the equity market and shows that the REIT share of the equity market increased steadily from 1985 to 1997 , with a rapid increase occurring in 1993. Aggregate public REITs' capitalization doubled that year. However, the well-known decline in the REIT market is evident beginning in 1998. REITs' equity capitalization, and its fraction of the stock market, has declined in recent years. By the end of 1999, the market capitalization of publicly traded REITs was $0.0007 \%$ of the whole equity market and the total value declined to about $\$ 120$ billion from about $\$ 138$ billion in late 1998 . Clearly, there could be huge growth in this market without it ever becoming a significant fraction of the overall stock market.

\section{Conclusion}

This article investigates the evolution of real estate in the economy. We focus on several important aspects of the economy, including GDP, household and corporate asset allocations, and the debt and equity markets. We develop indicators for each of these sectors and document the evolution of real estate since early $1980 \mathrm{~s}$. While previous efforts 
have relied on somewhat arbitrary and timeinvariant estimates, our analysis focuses on individual markets and therefore provides more accuracy. This focus allows us to see divergent patterns for real estate in different markets.

In terms of annual flows, real estate's share of GDP is quite stable over time. About $11 \%$ of new income or output created each year is added by the real estate industry. In contrast, the share of household and corporation assets allocated to real estate are decreasing over time. The strong performance of the stock market, growth in household wealth, the relatively low income elasticity of housing demand, and changes in corporate behavior investment behavior appear to be the major factors influencing this decline. Even so, the role of real estate in the dobt and equity markets has in creased substantially, indicating the importance of real estate finance innovations.

\section{Note}

1. Changes in tax code also may have affected the real entate share changes of the late 1980 s and early 1990s. The 1986 I'ax Reform Act dramatically changed depreciation deductions. The useful life of nonresidential property was $\mathrm{cx}$ tended from 19 yours to 31.5 years. The Accolerated Cost Recovery System, which often provided a much larger tax shelter for companies, was replaced by a straight-line depreciation method. In 1993, the useful life of nonresidentiat property was extended to 39 years. However, the effect of these events cannot account for the persistent decline in share. They may contribute to the real estate share decline in 1987 and 1993, but contribute less to the long-run trends in real estate decline.

\section{References}

L.S. Board of Governors of the Federal Reserve System, Flow of Funds Section, Flow of Funds Accounts of the United States: Flow Outstanding, Flow of Fund Z1, Washington, DC, 1999.

Gyourko, J. and Y. Jeng, Real Fstate Ownership by Non-Real Estate? Firms: The Impact on Firm Returns, Working paper, Wharton Zell / Lurie Real Estate? Center, Lniversity of I'ennsylvania, 1999.

Linneman, P., The Coming Disposal of Corporate Real Estate, Wharton Rerl Estate Retuew, 1998, 2:2.

Miles, M. and N. Tulleson, A Revised look at. How Real Esiate Compares with Other Major Components of Domestic Investment Lniverse, Real Estate Finance, Spring 1997.

Miles, M., f. Roberts, D. Machi and R. Hopkins, Sizing the Investment Markets: A Look at the Major Components of Public and Privatce Markets, Real Fstate Finunce, Spring 1994.

Wills, Ii., Truly Snart 'Smart Growth,' Illinois Real Estate Letter, Iniversity of Illinois at Urhana-Champaign, 1999.

Urban Land Insticute, Sources. Methods, and Evaluation of Data for America's Real Estate: Natural Resonere, National Legaty: Urban Land Institute website (last viewed June 2000 ).

This project is supported by the Research Sponsors Program of the Zell / Lurie Real Estate Center at the Wharton. School, University of Pennsyluania. The authors thank Joseph Gyourko, Yongheng Deng, James Shilling and Chris Mayer for helpoful comments. 